\title{
Optimization of productions of cellulolytic enzymes by Aspergillus niger using residue of mango a substrate
}

\author{
Otimização da produção de enzimas celulolíticas obtidas de Aspergillus niger utilizando o resíduo \\ da manga como substrato
}

\author{
Tamires Carvalho dos Santos ${ }^{I}$ Ingrid Souza Cavalcanti ${ }^{I}$ Renata Cristina Ferreira Bonomo \\ Nivio Batista Santana ${ }^{\mathrm{I}}$ Marcelo Franco ${ }^{*}$
}

\begin{abstract}
The present paper analyses the effects of water activity $(0.88,0.94$ and 0.97$)$ and of fermentation time (24, 48, 72, 96 and 120 hours) on the kinetic activity of enzymes cellulolytic, produced during the solid state fermentation of waste from the improvement of mango, with the aid of fungus species Aspergillus niger. Solid state fermentation was carried out at $35^{\circ} \mathrm{C}$ inside a bacteriological incubator. The statistical results indicated that the best activity for enzyme CMCase was $7.26 U \mathrm{~g}^{-1}$ after 74.51 hours of fermentation, whereas for enzyme FPase was $2.55 \mathrm{U} \mathrm{g}^{-1}$ after 98.52 hours, both presenting best results in approximately 0.928 of water activity. Pareto charts have showed that fermentation time has greater effect over the activity of enzyme CMCase, while the water activity variable has greater effect over enzyme FPase activity. During fermentation the fungus synthesized the enzymes without the need of inductors other than mango residue and water.
\end{abstract}

Key words: Aspergillus niger, Pareto charts, solid state fermentation, Mangifera indica. $L$.

\section{RESUMO}

Neste trabalho, foram analisados o efeito da atividade de água $(0,88,0,94$ e 0,97) e do tempo de fermentação $(24,48,72,96$ e 120 horas) sobre a atividade cinética das enzimas celulolíticas, produzidas durante a fermentação em estado sólido do resíduo do beneficiamento de manga com a utilização da espécie fúngica Aspergillus niger. A fermentação em estado sólido foi realizada a $35^{\circ} \mathrm{C} \mathrm{em}$ estufa bacteriológica. Os resultados estatísticos indicaram que a melhor atividade para a enzima CMCase foi de $7,26 \mathrm{U} \mathrm{g}^{-1}$ após 74,51 horas de fermentação, enquanto que para a enzima FPase esse valor foi de 2,55U $\mathrm{g}^{-1}$. Após 98,52 horas, através dos resultados obtidos pela aplicação da metodologia de superfície de resposta, ambas as enzimas apresentaram melhores resultados em aproximadamente 0,928 de atividade de água. Nos gráficos de Pareto, observamos que o tempo de fermentação tem maior efeito sobre a atividade da enzima CMCase, enquanto que a variável atividade de água exerce maior efeito sobre a atividade da enzima FPase. Durante a fermentação, o fungo secretou as enzimas sem a necessidade de qualquer indutor além do resíduo de manga e água.

Palavras-chave: Aspergillus niger, Gráfico de Pareto, fermentação em estado sólido, Mangifera indica. $L$.

\section{INTRODUCTION}

Waste output and byproducts are inherent to all productive sectors. With the improvement of ecological awareness by the end of the $20^{\text {th }}$ century, it became clear that humankind's major challenge for the coming decades is to balance the production of goods and services with economic growth, social equality and environmental sustainability(GALEMBECK et al., 2009).

Environmental concern leads to the feasibility of projects that promote the sustainability of production systems. Contrary to what happened in the past when waste was improperly disposed of, today's concepts of minimization, recovery and reuse of byproducts are being increasingly disseminated (LAUFENBERG et al., 2003; BALAT et al., 2008).

In Brazil, the quantity of agro-industrial byproducts such as bagasse, bran, peel and seeds in general is expressive, and nowadays, concepts

${ }^{\text {I}}$ Centro de Desenvolvimento e Difusão de Tecnologia, Universidade Estadual do Sudoeste da Bahia (UESB), Praça Primavera, n40, Bairro Primavera, 45700-000, Itapetinga, BA, Brasil. E-mail: marcelofranco@ pq.cnpq.br. *Autor para correspondência. 
involving minimization, recovery and reuse of such coproducts are being increasingly disseminated. Their use as raw material for bioprocesses has become feasible due to its low economic cost and its high availability, therefore research work involving bioprocesses has increased exponentially, its main focus being the search of products with high added value, such as enzymes, biofertilizers, biosurfactants and other microbial metabolites (COUTO \& SANROMAN, 2006).

VIEIRA et al. (2009) highlights that a few regions in the Amazon have the potential for mango cultivation, for example, in the state of Roraima, which is considered by many to be the barn of the Amazon production. By the end of the mango industrial processing, a large quantity of refuse is discarded, 40 and $60 \%$ of the raw material, composed mainly of peel and seeds. Owing to sanitary and environmental reasons, the disposal of waste must be effected far from the processing unit, preferably in landfills, composting units or thermoelectric plants, and this brings additional costs (PURAVANKARA et al., 2000).

A high portion of the co-products generated during fruit processing is made of cellulose, hemicellulose and lignin, which are known as lignocellulosic compounds. Cellulose is the most abundant biopolymer available in the world and through its hydrolysis it is possible to obtain glucose (GALEMBECK et al., 2009). The cellulase hydrolytic process takes place via an enzymatic complex of cellulases (TENGERDY \& SZAKACS, 2003). Such enzymes are biocatalyzers working in synergy to release sugars, of which glucose attracts most of the interest from industry, due to the possibility of converting it into ethanol (SOCCOL et al., 2010). There is a large variety of cellulolytic microorganisms in nature, however, only a few are known as being truly cellulolytic, that is, being able to break down natural cellulose (CAMASSOLA \& DILLON, 2010).

Solid state fermentation is understood as being the growth of a culture of microorganisms on or within solid particles (GERVAIS \& MOLIN, 2003). The liquid content bonded to the solid matrix is at a level of water activity that, on one hand, assures the growth and metabolism of the cells, while on the other, it does not exceed the maximum bonding capacity of the water with the solid matrix (SINGHANIA et al., 2009). The microorganisms usually employed in SSF are fungi, yeast and bacteria, of which we highlight the fungi. Research work on the bioconversion of agro-industrial waste is increasingly developing, because from this process it is possible to synthesize a number of compounds for industrial application (PANDEY, 2000).
The solid fermentation process becomes more efficient with the use of filamentous fungi (HOLKER et al., 2004). Fungi of the Aspergillus genus are economically important, and are used in numerous fermentations, including the production of organic acids and biosurfactants, and is also the most used microorganism in the production of enzymes (HAQA et al., 2003).

The ability of decomposing cellulosic biomass into glucose, which may be converted into added value products and energy, has turned cellulase into one of the most investigated multicomponent enzyme systems (TENGERDY \& SZAKACS, 2003). The objective of this study is to optimize the production of exogluconases and endogluconases by applying solid state fermentation to the waste of mango improvement.

\section{MATERIAL AND METHODS}

The microorganism studied was a strain of Aspergillus niger of the Agro-Industrial Residue Laboratory - LABRA of the Bahia Southeast State University - UESB, Itapetinga campus. The waste was provided by a fruit pulp improvement agro-industry located in the southeast region of Bahia, dried in a SOLAB drying and sterilization incubator at $70^{\circ} \mathrm{C}$ for 24 hours and then grinded to an approximate grain size of $0.2 \mathrm{~mm}$ grinding of the biomass is necessary to reduce cellulose crystallinity. The process increases the material's contact surface, which is important for the fermentation processes.

The sporulated culture (inclined, acidified PDA HIMEDIA) incubated at $35^{\circ} \mathrm{C}$ for 7 days in a bacteriological incubator (model SL 101 SOLAB) was suspended in Tween 80 (VETEC) solution. The number of spores in suspension was counted using a double mirror Neubauer chamber and a binocular BIOVAL L1000 microscope.

The assays were carried out in Erlenmeyers flasks containing $10 \mathrm{~g}$ of mango waste, to which were added $5 \mathrm{ml}, 10 \mathrm{ml}$ and $15 \mathrm{ml}$ of sterile water the water activity values were $0.88,0.94$ and 0.97 respectively, and were determined in a BASEQ aqualab. The flasks containing waste and water medium were sterilized in autoclaving at $121^{\circ} \mathrm{C}$ for $1 \mathrm{~h}$. A quantity of $10^{7}$ spores per gram of dry basis substratum was added to the suspension. The incubations were conducted at $35^{\circ} \mathrm{C}$ in a SOLAB model SL 101 bacteriological incubator. Following the fermentation process, the enzyme extract was mechanically extracted with a $50 \mathrm{~mL}$ sodium citrate tampon solution (VETEC) with a pH of 4.8 at 50mM. The enzyme extract that resulted from the fermentation was centrifuged at $900 \mathrm{G}$-force for 10 minutes in a CETRIBIO model 80-2B centrifuge. 
The method chosen to determine the activity of CMCase is based on the dose of reducing sugars produced by the degradation of carboxymethylcellulose (CROMOLINE) at $2 \%$ per volume previously diluted in a sodium citrate solution with a $\mathrm{pH}$ of 4.8 at $50 \mathrm{mM}$. The dinitrosalicylic acid method was used for quantification (DNS) (MILLER, 1959). Reaction assays were conducted by adding to an assay tube $0.5 \mathrm{~mL}$ of sodium citrate tampon solution with a pH of 4.8 at $50 \mathrm{mM}, 0.5 \mathrm{~mL}$ of enzyme extract and $0.5 \mathrm{~mL}$ of CMC ( $2 \%$ per volume). The reaction control was carried out in another tube, to which were added $0.5 \mathrm{~mL}$ of the same tampon solution and $0.5 \mathrm{~mL}$ of enzyme extract. The samples were incubated in a bacteriological incubator, subjected to QUIMIS orbital shaking at $50^{\circ} \mathrm{C}$ and $150 \mathrm{rpm}$ for 10 minutes. The reaction was interrupted with the addition of $0.5 \mathrm{~mL}$ of DNS. The tubes were submerged in boiling water for 5 minutes and soon after, $6.5 \mathrm{~mL}$ of distilled water were added for a subsequent measurement of absorbance in the $540 \mathrm{~nm}$ range, carried out in a BEL PHOTONICS 2000UV spectrophotometer.

The FPase activity, that is, filter paper activity, results from the degradation of a strip of Whatman filter paper $\mathrm{n}-1$ measuring $1.0 \mathrm{~cm} \times 6.0 \mathrm{~cm}$ (SANTOS et al., 2011). The tube containing the reaction assay received the addition of $1.0 \mathrm{~mL}$ of a sodium citrate tampon solution with a pH of 4.8 at $50 \mathrm{mM}, 0.5 \mathrm{~mL}$ of enzyme extract and a strip of filter paper. Another tube received the addition of $1 \mathrm{~mL}$ of the same tampon solution and $0.5 \mathrm{~mL}$ of enzyme extract. The third tube, which was the substratum control, received the addition of $1.5 \mathrm{~mL}$ of tampon solution and a strip of filter paper. The samples were left in an incubator at $50^{\circ} \mathrm{C}$ for 1 hour. The reaction was interrupted with the addition of $3 \mathrm{ml}$ of DNS. The tubes were placed in boiling water for 5 minutes and soon after $20 \mathrm{~mL}$ of distilled water were added for the subsequent measurement of absorbance in the 540nm range, carried out in a spectrophotometer.

The standard curve was plotted with the determination of glucose in concentrations of 0.2 to $1.0 \mathrm{~g} \mathrm{~L}^{-1}$ using the DNS method described by MILLER (1959). The enzyme activity unit (U) was defined as being the quantity of enzyme capable of releasing 1 $\mu \mathrm{mol}$ of reducing sugars per minute at $50^{\circ} \mathrm{C}$, the enzyme activity being expressed in $\mathrm{U} \mathrm{g}^{-1}$. Absorbance was measured in a model SP 2000UV spectrophotometer.

The experiments were carried out in an entirely randomized design (ERD) with treatments organized in a $3 \times 5$ factor scheme with 2 repetitions, totaling 30 experimental points. Three levels of water activity were used $(0.88,0.94,0.97)$ as well as five levels of time factor (24h, 48h, 72h, 96h, 120h). The results obtained were analyzed using Analysis Variance
(ANOVA) with a $5 \%$ probability for the $\mathrm{F}$ test (Fisher) and Regression Analysis for the significance of parameters (Student Test, $\mathrm{P}<0.10$ ), analysis of residues and coefficient of determination $\left(\mathrm{R}^{2}\right)$. All statistical analyses were conducted using the statistics program package SAEG, v.8.1 (RIBEIRO, 2001).

\section{RESULTS AND DISCUSSION}

The experimental results for enzyme activity under the water activity and time conditions studied were submitted to ANOVA and regression analysis. The regression analysis was carried out in order to adjust the mathematical models to the experiment data with the objective of identifying an optimal region for the variable answer studied (enzyme activity) in the light of the established independent variables (fermentation time and water activity). The two independent variables had a significant effect on both enzymes. The behavior of the systems studied can be described by a second-order polynomial model (Equations 1 and 2), where the term of interaction among the independent variables was non-significant $(\mathrm{P}>0.10)$. The quadratic model for both variables adjusted for each of the enzymes studied showed the results $\mathrm{R}^{2}=0.81$ and $\mathrm{R}^{2}=0.73$ respectively, for $\mathrm{CMCase}$ and FPase. From figure 1, Pareto charts, it is possible to verify that for CMCase, the fermentation time has a more significant effect over enzyme activity, whereas for enzyme FPase the water activity variable is the one having more significant effect.

The equations were generated to fit the experimental data using response surface methodology for the optimization of experimental parameters, as shown below. The reduced models concerning each enzyme and microrganism are described by the equations 1 and 2 :

$\mathrm{A}_{\mathrm{CM}}=-881,864+1896,34 \mathrm{a}_{\mathrm{w}}-1021,12 \mathrm{a}_{\mathrm{w}}{ }^{2}+0,233250 \mathrm{t}-$ $0,00156527 \mathrm{t}^{2}$

$A_{\mathrm{FP}}=-679,697+1468,76 \mathrm{a}_{\mathrm{w}}-792,633 \mathrm{a}_{\mathrm{w}}{ }^{2}+0,0372726 \mathrm{t}-$ $0,000189167 \mathrm{t}^{2}$.

These regression models were used to determine the response surface concerning the response variable by relating two independent variables, as shown in figure 2 .

Figure 2 illustrates combinations of the effects of independent variables on enzyme activity, and through the derivatives of equations 1 and 2 we can observe that the optimal activity point for enzyme CMCase was at time $74.51 \mathrm{~h}$ and water activity 0.929 , whereas for enzyme FPase time was $98.52 \mathrm{~h}$ and water activity 0.927 (Table 1). We highlight that the fungus synthesized the enzyme (7.26 $\mathrm{U} \mathrm{g}^{-1}$ for CMCase and 


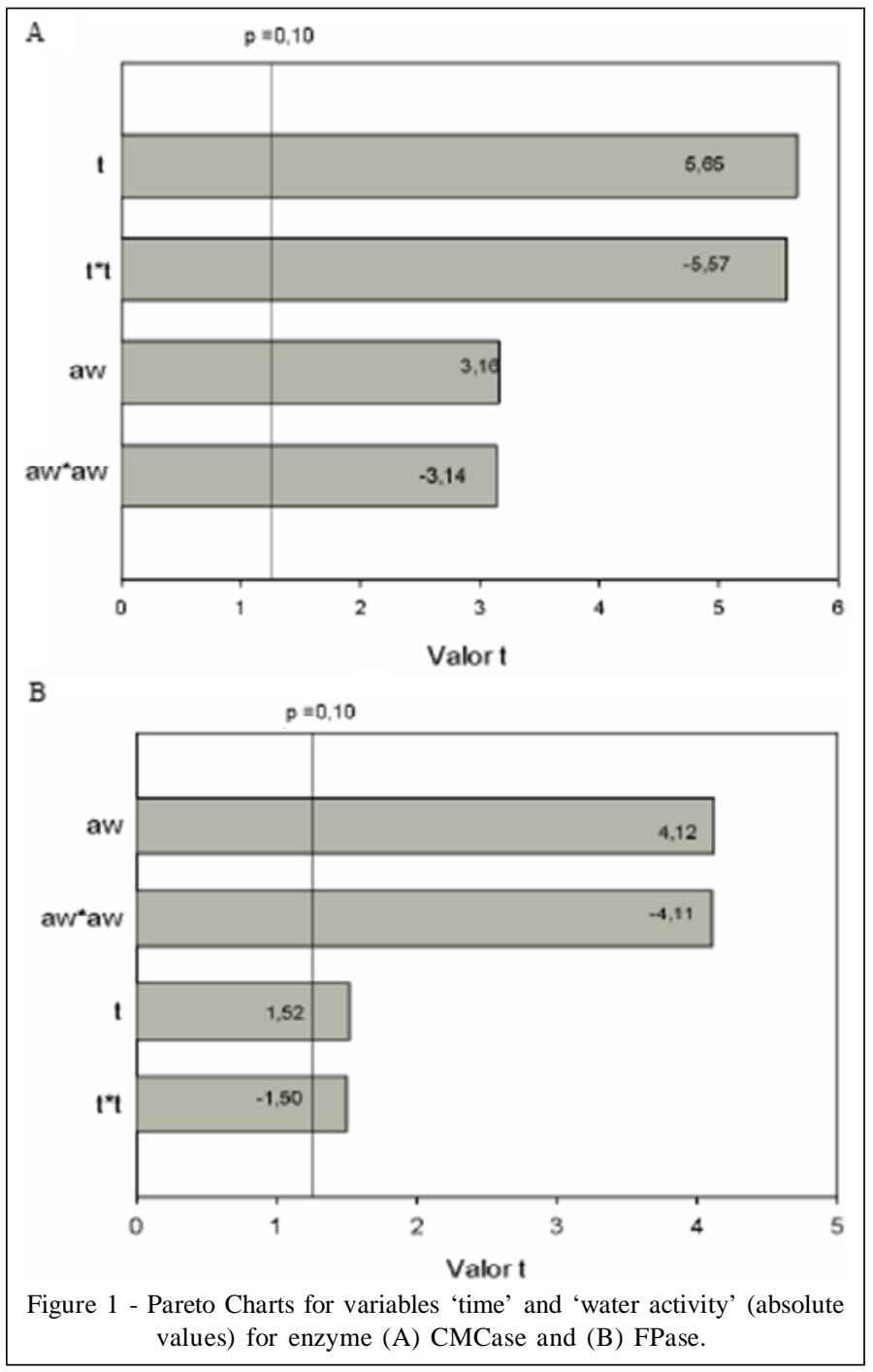

$2.55 \mathrm{U} \mathrm{g}^{-1}$ for FPase) without the need of any inductors or supplies other than the mango waste and water at various concentrations, thereby demonstrating that it is a constitutive enzyme.

Enzymes usually have expression control mechanism that can be stimulated or inhibited by products of the medium. The end products of a particular metabolic pathway are often inhibitors of enzymes that catalyze the first steps of the pathway. This mechanism is known as negative feedback. BIAZUS et al. (2006), working with corn malt, noted that in the production of enzymes the beginning is slow, then accelerates until it reaches its maximum value, thereafter, the concentration of products generated are inhibited and its activity is reduced, which was also observed in this study. OMEMU, et al. (2005) obtained higher yields of cassava starch hydrolysis by $A$. niger after 72 hours of fermentation, which agrees with ALVA et al. (2007), who also reported a higher enzymatic activity by Aspergillus. The decrease in activity with increasing incubation time may be due to the production of by-products resulting from microbial metabolism, besides of nutrient depletion, inhibiting the growth of the fungus and formation of the enzyme (SHAFIQUE et al., 2009).

The literature shows the production of endoglucanases by actinomycetes, particularly Streptomyces, on different substrates. The strain of Streptomyces T3-1, produced $40.3 \mathrm{U} \mathrm{mL}^{-1}$ in $1.5 \% \mathrm{CMC}^{-}$ and ammonium sulfate, urea and peptone (JANG \& CHEN 2003), but these nutrients were not used with low cost substrates. Streptomyces sp. isolated from Canadian soil was cultivated in a solution containing Mandel peptone, $1.0 \%$ Tween 80 in crystalline cellulose and produced $11.8 \mathrm{U} \mathrm{mL}^{-1}$ of CMCase (ALANI et al., 2008) however, Thermomonospora sp. (GEORGEet al., 2001) when grown 


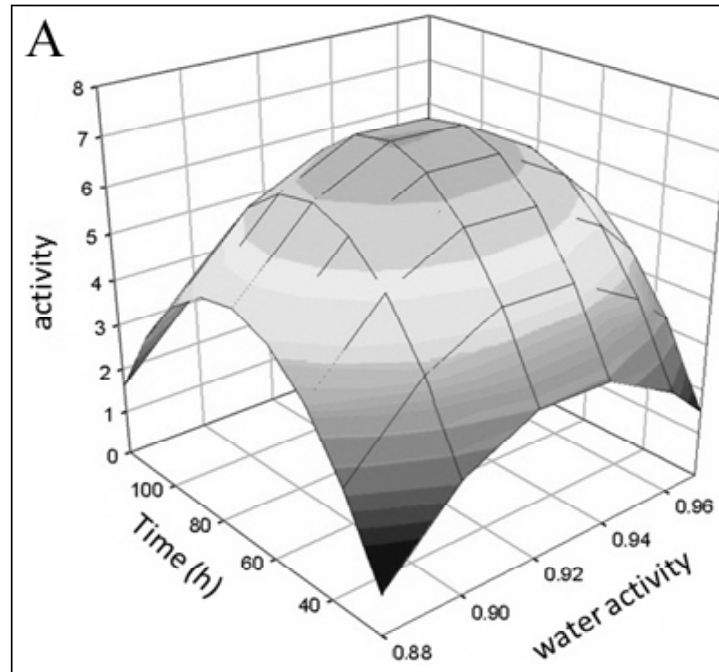

B

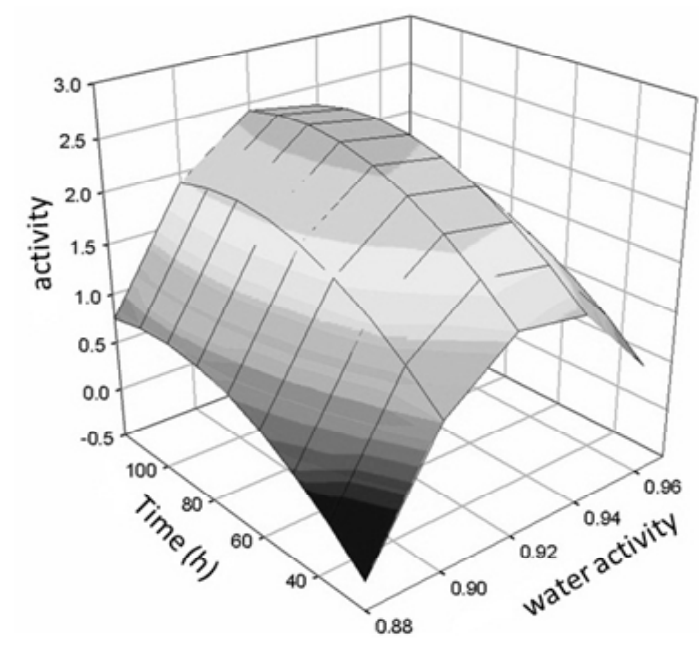

Figure 2 - The effects of fermentation time and water activity on enzyme activity: (A) CMCase e (B) FPase.

on medium containing cellulose paper powder, yeast extract and Tween 80 , showed a peak of $23 \mathrm{UmL}^{-1}$, whereas when grown on wheat bran activity was $8.5 \mathrm{U} \mathrm{mL}^{-1}$. JORGENSEN \& OLSSON, (2006) working with Penicillium brasilianum IBT in a bioreactor in medium containing yeast extract and a type of wood from pine subjected to steam explosion, values of $0.59 \mathrm{U} \mathrm{mL} \mathrm{m}^{-1}$ FPase. Trichoderma viride NCIM 1051 in $1.0 \%$ of sugarcane bagasse treated with $\mathrm{NaOH}$ resulted in an FPase activity of $0.4 \mathrm{U} \mathrm{mL}^{-1}$ (ADSUL et al., 2004). Aspergillus niger IZ9 in medium containing sugarcane bagasse treated with sodium hydroxide $(\mathrm{NaOH})$ showed peak activity of $0.2 \mathrm{UmL}^{-1}$ (AGUIAR \& MENEZES 2000).

The water activity interval in which microbial development takes place in general ranges from 0.60 to 0.99 , and the optimal value for growth oscilates between 0.90 and 0.99 (GERVAIS \& MOLIN 2003). The water content is a factor that interferes with the excretion of enzymes by microorganisms. In solidstate fermentation the moisture promotes the growth of fungi through the transfer of $\mathrm{O}_{2}$, diffusion of nutrients in the solid substrate and temperature control. As the water content is limited, its control is essential to optimize the solid-state fermentation. The ideal water content forms an aqueous film on the surface, which facilitates the dissolution and transfer of nutrients and oxygen (GERVAIS \& MOLIN 2003). In the present study, it has been observed that starting from water activity between 0.95 and 0.98 , there was a drop in production for both studied enzymes. That could be related with fungal inhibition, marked by the extrapolation of the ideal water level for the development of the selected lineage, which could be influencing the metabolic route responsible for enzyme production.

The fungus used was shown to be effective enzyme production by fermentation, as mentioned by PANDEY et al. (2000) which points out that the microorganism Aspergillus is the most widely used enzyme production. The mathematical modeling of fermentation processes can be defined as the attempt to represent, mathematical equations, the mass balances, associated with biochemical changes that occur in the process and the speed with which these transformations take place.

\section{CONCLUSION}

The waste mango can be used as feedstock for the production of cellulolytic enzymes by cultivating the filamentous fungus Aspergillus niger by solid state fermentation. The differential performance in the production of enzymes demonstrated decreased the importance of mathematical modeling. Pareto charts, it is possible to verify that for CMCase, the fermentation

Table 1 - Optimal values for the effects time and water activity and temperature to enzymatic.

\begin{tabular}{lcccc}
\hline Enzyme & Time $(\mathrm{h})$ & Water activity & Temperature $\left({ }^{\circ} \mathrm{C}\right)$ & enzymatic activity $\left(\mathrm{U} \mathrm{g}^{-1}\right)$ \\
\hline CMCase & 71.54 & 0.929 & 35 & 7.26 \\
FPase & 98.52 & 0.927 & 35 & 2.55 \\
\hline
\end{tabular}

Ciência Rural, v.41, n.12, dez, 2011. 
time has a more significant effect over enzyme activity, whereas for enzyme FPase the water activity variable is the one having more significant effect.

\section{ACKNOWLEDGEMENT}

The authors are thankful to the Conselho Nacional de Desenvolvimento Científico e Tecnológico ( $\mathrm{CNPq}$ ) for granting the ITI scholarship (Industrial Technology Initiation) and the Brazil Northeast Bank (BNB) for granting financial support.

\section{REFERENCES}

ADSUL, M.G et al. Polysaccharides from bagasse: applications in cellulase and xylanase production. Carbohydrate Polymers, v.57, 67-72, 2004. Available from: <http:// www.sciencedirect.com/science/article/pi i/ S014486170400089X>. Accessed: Jan 10, 2011. doi:10.1016/ j.carbpol.2004.04.001.

AGUIAR, C.L.; MENEZES, T.J.B. Produção de celulases e xilanase por Aspergillus niger IZ-9 usando fermentação submersa sobre bagaço de cana de açúcar. Boletim do Ceppa, v.18, 5770, 2000. Available from: <http://ojs.c3sl.ufpr.br/ojs2/ index.php/alimentos/article/view/1125/926>. Accessed: Mar 02,2011

ALANI, F. et al. New isolate of Streptomyces sp. with novel thermoalkalotolerant cellulases. Biotechnology Letters, v.30, 123-126, 2008. Available from: <http://www.springerlink.com/ content/b5t4m43994067muk/fulltext.pdf>. Accessed: Set 12, 2010. doi: 10.1007/s10529-007-9500-9.

ALVA, S. et al. Production and characterization of fungal amylase enzyme isolated from Aspergillus sp. JGI 12 in solid state culture. African Journal of Biotechnology, v.6, 576-581, 2007. Available from: <http://academicjournals.org/ajb/PDF/pdf2007/ 5Mar/Alva\%20et\%20al.pdf >. Accessed: Oct 19, 2010.

BALAT, M. et al. Progress in bioethanol processing. Progress in Energy and Combustion Science, v.34, 551573, 2008. Available from: <http://www.sciencedirect.com/ science?_ob=MiamiImageURL\&_cid=271467\&_user=3449915 \&_pii=S0360128507000706\&_check $=y \& \_$origin $=\&$ \&coverDate $=31-\mathrm{Oct}-2008 \& \mathrm{vi}$ e $\mathrm{w}=\mathrm{c} \& \mathrm{wch} \mathrm{p}=\mathrm{d} \mathrm{G} \mathrm{L} \mathrm{b} \mathrm{V} 1 \mathrm{k}-$ zSkWA\&md5=aed35e32d74b22eece005bbf02e0e4c8/1-s2.0 S0360128507000706-main.pdf>. Accessed: set 14, 2009. doi: 10.1016/j.pecs.2007.11.00.

BIAZUS, J.P.M. et al. Otimização da secagem do malte de Zea mays. Ciência e Tecnologia de Alimentos, v.26, 787-792, 2006. Available from: <http://www.scielo.br/ scielo.php?script=sci_arttext\&pid=S0101$20612006000400012 \& \operatorname{lng}=\mathrm{pt} \& \mathrm{nrm}=\mathrm{i}$ so \& $\mathrm{t} \operatorname{lng}=\mathrm{pt}>$. Accessed: Mar 28, 2010. doi.org/10.1590/S010120612006000400014.

CAMASSOLA, M.; DILlON, A.J.P. Cellulases and xylanases production by Penicillium echinulatum grown on sugar cane bagasse in solid-state fermentation. Applied Biochemistry and Biotechnology, v.162, p.1889-1900, 2010. Available from: <http://www.springerlink.com/content/g16g270256r23167>. Accessed: Jan 25, 2011. doi: 10.1007/s12010-010-8967-3.
COUTO, S.R.; SANROMAN, M.A. Application of solid-state fermentation to food industry, a review. Journal of Food Enginnering, v.76, p.291-302, 2006. Available from: <http:/ / www.sciencedirect.com/science/article/pii/ S0260877405003584>. Accessed: Jul 06, 2009. doi:10.1016/ j.jfoodeng.2005.05.02

GALEMBECK, F. et al. Aproveitamento sustentável de biomassa e de recursos naturais na inovação química. Química Nova, v.32, p.571-581, 2009. Available from: <http://quimicanova.sbq.org.br/ qn/qnol/2009/vol32n3/02-QN09149.pdf>. Accessed: Set 12, 2010. doi: $10.1590 /$ S0100-40422009000300003

GEORGE, S.P. et al. Studies on carboxymethyl cellulose produced by an alkalothermophilic actinomycete. Bioresource Technology, v.77, p.171-175, 2001. Available from: <http:// www.sciencedirect.com/science/article/pi / S0960852400001504>. Accessed: Set 12, 2008. doi:10.1016/ S0960-8524(00)00150-4.

GERVAIS, P.; MOLIN, P. The role of water in solid-state fermentation. Biochemical Engineering Journal, v.13, p.85-101, 2003. Available from: <http://www.sciencedirect.com/ science/article/pii/S1369703X02001225> Accessed: may 12, 2009. doi: 10.1016/S1369-703X(02)00122-5.

HAG, I. et al. Direct production of citric acid from raw starch by Aspergillus niger. Process Biochemistry, v.38, n.6, p.921924, 2003. Available from: <http://www.sciencedirect.com/ science/article/pii/S0032959202002017>. Accessed: Jun 22, 2010. doi:10.1016/S0032-9592(02)00201-7.

HOLKER, U. et al. Biotecnological advantages of laboratoryscale solid-state fermentation with fungi. Applied Microbiology and Biotechnology, v.64, p.175-186, 2004. Available from: <http://www.londonmet.ac.uk/fms/LondonMet/ A c a d e m i c \% $20 \mathrm{Admin/A} \mathrm{I} \mathrm{U/Cousework/}$ Autumn\%20Semester\%200708/SeenCaseStudiesMaterials/ NFP007N\%20Case\%20Study\%20Holker\%20et\%20al_\%202004.pdf〉. Accessed: Nov 02, 2009. doi 10.1007/s00253-003-1504-3.

JANG, H.D.; CHEN, K.S. Production and characterization of thermostable cellulases from Streptomyces transformant T3-1. World Journal of Microbiology and Biotechnology, v.19, p.263-268, 2003. Available from: <http://www.springerlink.com/ content/v30744h52660743x/fulltext.pdf >. Accessed: Set 18, 2008. doi: 10.1007/s10529-004-8356-5.

JORGENSEN, H.; OLSSON, L. Production of cellulases by Penicillium brasilianum IBT 20888 - Effect of substrate on hydrolytic performance. Enzyme and Microbial Technology, v.351, p.381-390, 2006. Available from: <http:// www.sciencedirect.com/science/article/pii/ S0141022905002991>. Accessed: May 21, 2010. doi:10.1016/ j.enzmictec.2005.06.018.

LAUFENBERG, G. et al. Transformation of vegetable waste into value added products: (A) the uppgrading concept (B) Pratical implementations. Bioresource Technology, v.87, p.167-198, 2003. Available from: <http://infolib.hua.edu.vn/ Fulltext/ChuyenDe2009/CD158/34.pdf>. Accessed: May 12, 2007. doi:10.1016/S0960-8524(02)00167-0.

MILLER, G.L. Use of dinitrosalicylic acid reagent for determination of reducing sugar. Analytical Chemistry, v.31, p.426-428, 1959. Available from: <http://pubs.acs.org/doi/abs/ 10.1021/ac60147a030>. Accessed: Aug 29, 2005. doi: 10.1021/ ac60147a030. 
OMEMU, A.M. et al. Hydrolysis of raw tuber starches by amylase of Aspergillus niger AM07 isolated from the soil. African Journal of Biotechnology. v.4, p.19-25, 2005. Available from: <https://tspace.library.utoronto.ca/bitstream/ 1807/6581/1/jb05004.pdf>. Accessed: set 21, 2007.

PANDEY, A. et al. Biotechological potential of agro-industrial residues. II: cassava bagasse. Bioresource Tecnology, v.74, p.81-87, 2000. Available from: <http://www.sciencedirect.com/ science/article/pii/S0960852499001431>. Accessed: Aug 04, 2004. doi:10.1016/S0960-8524(99)00143-1.

PURAVANKARA, D. et al. Effect of antioxidant principles isolated from mango (Mangifera indica $L$.) seed kernels on oxidative stability of buffalo ghee (butter-fat). Journal of the Science of Food and Agriculture, v.80, p.522-526, 2000. Available from: <http://onlinelibrary.wiley.com/doi/ 10.1002/(SICI) 1097-0010(200003)80:4\%3C522::AIDJSFA560\%3E3.0.CO;2-R/abstract>. Accessed: Set 01, 2009. doi: $10.1002 /($ SICI) $1097-0010(200003) 80: 4<522:: A I D-$ JSFA560>3.0.CO;2-R.

RIBEIRO JÚNIOR, J.I. Análises estatísticas no SAEG. Viçosa: UFV, 2001. 301p.

SANTOS, T.C. et al. Determinação da atividade de CMCase e FPase da estipe fúngica Rhizopus sp. através da bioconversão do resíduo de seriguela (Spondias purpúrea L.). Unopar Científica Ciências Biológicas e da Saúde, v.13, p.145149, 2011. Available from: <http://www12.unopar.br/unopar/ pesquisa/rcArtigos.action>. Acessed: May 20, 2011.
SHAFIQUE, S. et al. Screening of Aspergillus niger and $\boldsymbol{A}$. flavus strains for extra cellular alpha-amylase activity. Pakistan Journal of Botany, v.41, p.897-905, 2009. Available from: <http://www.pakbs.org/pjbot/PDFs/41(2)/ PJB41(2)897.pdf>. Accessed: Nov 17, 2010.

SINGHANIA, R.R. et al. Recent advances in solid-state fermentation. Biochemical Engineering Journal, v.44, p.13-18, 2009. Available from: <http://www.sciencedirect.com/ science/article/pii/S1369703X08003331>. Accessed: Set 19, 2010. doi:10.1016/j.bej.2008.10.019.

SOCCOL, C.R. et al. Bioethanol from lignocelluloses: Status and perspectives in Brazil. Bioresource Technology, v.101, p.48204825, 2010. Available from: <http://www.sciencedirect.com/ science/article/pii/S0960852409015727>. Accessed: Jan 10, 2011. doi:10.1016/j.biortech.2009.11.067.

VIEIRA, P.A.F. et al. Caracterização química do resíduo do Processamento agroindustrial da manga (Mangifera indica L.) Var. Ubá. Alimentos e Nutrição, v.20, p.617-623, 2009. Available from: <http://serv-bib.fcfar.unesp.br/seer/index.php/ alimentos/article/viewFile/1240/867>. Accessed: Set 27, 2010.

TENGERDY, R.P.; SZAKACS, G. Bioconversion of lignocellulose in solid substrate fermentation. Biochemical Engineering Journal, v.13, p.169-17, 2003. Available from: <http://www.sciencedirect.com/science/article/pii/ S1369703X02001298>. Accessed: Set 14. 2005. doi:10.1016/ S1369-703X(02)00129-8. 